\title{
The Psychological Impact and Stressors of Quarantine during the Respiratory Infectious Diseases Pandemic
}

\author{
Xiuwan CHEN and Haihua ZHU* \\ Nursing Department, First Affiliated Hospital, Xiamen University, P. R. China \\ *Corresponding author: Haihua ZHU, Nursing Department, First Affiliated Hospital, Xiamen University, P. R. China
}

\begin{tabular}{|c|c|}
\hline ARTICLE INFO & Abstract \\
\hline Received: May 08, 2020 & \multirow{2}{*}{$\begin{array}{l}\text { Citation: Xiuwan CHEN, Haihua ZHU. The Psychological Impact and Stressors of Quar- } \\
\text { antine during the Respiratory Infectious Diseases Pandemic. Biomed J Sci \& Tech Res } \\
\text { 27(5)-2020. BJSTR. MS.ID.004554. }\end{array}$} \\
\hline Published: May 20, 2020 & \\
\hline
\end{tabular}

\section{Introduction}

Quarantine refers to the restriction and separation of people who have potentially been exposed to an infectious disease to confirm whether they are unwell, so as to reduce the risk of infecting others [1]. Isolation, which is different from quarantine, is defined as the separation between people who have been diagnosed with infectious diseases and those who do not; however, they are often used interchangeably, especially when communicating with the public [2]. Recently, quarantine has been used to prevent and control the coronavirus disease 2019 (COVID-19) during the pandemic. Lots of countries require people who have potentially been in contact with to the virus infection to isolate themselves in a special quarantine facility or at home. The entire cities in China have effectively been placed under large-scale quarantine, while thousands of foreigners returning from China have been required to self-isolate themselves at home or in state-owned facilities [3]. However, quarantine is often a terrible and unpleasant experience for people who undergo it. Loss of freedom, uncertainty of disease status, and separation from loved ones create enormous effects.

The potential benefits and possible psychological costs of mandatory mass quarantine need to be carefully weighed [4]. As an effective public health measure, successful use of quarantine requires us to minimize the negative impact related to it. We undertook a mini review on the psychological impact of quarantine to discuss its possible effects on the psychological wellbeing and mental health, and the possible stressors that contribute to these effects. Previous studies showed psychological outcomes for different quarantined population. Medical staffs who directly came into contact with SARS more likely to report acute stress disorder, exhaustion, anxiety and so on [5]. Children who were quarantined are more vulnerable to the post-traumatic stress symptoms compared with those who were not quarantined, and $28 \%$ of parents quarantined were reported to have a trauma related mental health disorder [6]. However, another study found no significant difference between quarantined undergraduates and not quarantined undergraduates [7].

Several studies showed the related quarantine of stressors, such as duration of quarantine, inadequate supplies and information, as well as fears of infection. The duration of quarantine is longer, the avoidance, angry behaviors are more common [8]. Having inadequate basic supplies such as water, food during quarantine have been associated with anxiety and anger for a long time after release [9]. What's more, people during quarantine also face challenges in accessing enough medical care and personal protection equipment [10]. In addition, many participants used poor information from public health authorities as a source of stress, reporting that clear guidelines for action were inadequate and did not know the purpose of quarantine. Overall, our study indicates that the psychological impact of quarantine is substantial and continuous. Since quarantine is necessary and essential, how to take some measures according to stressors so as to lighten the unpleasant experience during quarantine is further study.

\section{References}

1. (2017) Centers for Disease Control and Prevention. Quarantine and isolation.

2. Manuell ME, Cukor J (2011) Mother Nature versus human nature: public compliance with evacuation and quarantine. Disasters 35(2): 417-442 
3. (2020) Public Health England. Novel coronavirus(2019nCoV)-what you need to know.

4. Rubin GJ, Wessely S (2020) The psychological effects of quarantining a city. BMJ 368: m313.

5. Bai Y, Lin CC, Lin CY, Chen JY, Chue CM, et al. (2004) Survey of stress reactions among health care workers involved with the SARS outbreak. Psychiatr Serv 55(9): 1055-1057.

6. Sprang G, Silman M (2013) Posttraumatic stress disorder in parents and youth after health $\neg$ related disasters. Disaster Med Public Health Prep $7(1): 105-110$.

7. Wang $Y, X u$ B, Zhao G, Cao R, He X, et al. (2011) Is quarantine related to immediate negative psychological consequences during the 2009 H1N1 epidemic? Gen Hosp Psychiatry 33(1): 75-77.

ISSN: 2574-1241

DOI: $10.26717 /$ BJSTR.2020.27.004554

Haihua ZHU. Biomed J Sci \& Tech Res

(C) This work is licensed under Creative

Submission Link: https://biomedres.us/submit-manuscript.php
8. Marjanovic Z, Greenglass ER, Coffey S (2007) The relevance of psychosocial variables and working conditions in predicting nurses coping strategies during the SARS crisis: an online questionnaire survey. Int J Nurs Stud 44(6): 991-998.

9. Wilken JA, Pordell P, Goode B, Jarteh R, Miller Z, et al. (2017) Knowledge, attitudes, and practices among members of households actively monitored or quarantined to prevent transmission of Ebola virus disease-Margibi County, Liberia: February-March 2015. Prehosp Disaster Med 32(6): 673-678.

10. Blendon RJ, Benson JM, DesRoches CM, Raleigh E, Taylor Clark K (2004) The public's response to severe acute respiratory syndrome in Toronto and the United States. Clin Infect Dis 38: 925-931.

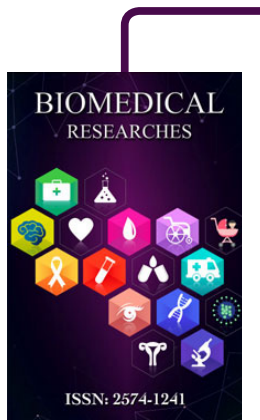

\section{Assets of Publishing with us}

- Global archiving of articles

- Immediate, unrestricted online access

- Rigorous Peer Review Process

- Authors Retain Copyrights

- Unique DOI for all articles 